\title{
PUT YOUR MONEY WHERE YOUR MOUTH IS - PARTICIPATORY BUDGETING IN ROMANIAN CITIES
}

\author{
Nicolae Urs ${ }^{1}$
}

DOI: $10.24989 /$ ocg.338.24

\begin{abstract}
Almost 40 years ago, New Public Management theorists reserved an increasingly important role for citizens and civil society in the policy making process. This trend continued afterwards with proponents of Digital Era Governance or New Public Service theories. But without the opportunity of taking decisions on how to spend at least some parts of the government money, the influence of citizens and $\mathrm{NGOs}$ is fairly limited.
\end{abstract}

Local governments, as the institutions closer to the needs and wishes of the communities, have gradually taken note of the increasing clamor for more power and transparency. Participatory budgeting processes have sprung up all over the world in the last years. Romania is no exception; a number of cities have implemented platforms that allow their citizens to propose and vote on projects to improve the quality of life in their communities.

Our research will try to ascertain the level of success such initiatives have in Romania, a country with a generally low level of civic engagement. For this, we will use questionnaires and interviews with public servants in charge of these platforms.

Keywords: participatory budgeting, Romania, e-participation

\section{Introduction}

Governments are losing the trust of the population. Or so is the general sentiment among the public, and the view among a lot of media outlets that periodically publish articles and video stories that try to find the reasons for this perceived loss of trust. Some researchers agree that this loss of trust is indeed happening [8], some do not [6], but for elected political figures, with an eye on TV screens and twitter influencers, the perception is at least as important as the reality.

A lot of factors influence citizens' trust in their governments: the economic situation of the country, political upheavals, the level of authoritarianism, corruption perception, and a myriad other events that can have a salient or enduring effect on public trust in institutions.

On the other hand, it is universally recognized that a society that exhibits a high level of trust enjoys multiple benefits, such as economic involvement (people are more willing to spend and invest if they trust the government), or civic engagement (people are more inclined to work together to help solve communities problems). Also, official initiatives are more likely to work and citizens are more willing to pay their taxes and abide the law if they think that these are fair.

\footnotetext{
${ }^{1}$ Babeş-Bolyai University, Cluj-Napoca, nicu@fspac.ro
} 
Some researches show that heavy internet users have a lower trust level in government; however, this level can be increased if e-government services are properly implemented [14]. Other studies show that even if good online services do not significantly increase trust, bad services definitely decrease it [6].

Both local and national governments throughout the world are trying to engage with citizens, companies and NGOs, for a number of reasons. New Public Management and then Digital Era Governance and New Public Service theories assign an increasingly important role to citizens and organizations outside public administration in deciding public policies. This wave of growing democratic participation is relaying more and more on technology to connect citizens, institutions and organizations. The tools employed and perfected by commercial companies, many originated in Silicon Valley, are repurposed or reimagined with the lofty goal of increasing public involvement in running communities or countries.

A common catch-all for this initiatives is e-participation, which can be defined as "the use of digital tools for political participation" [2] and includes o wide range of tools, both formalized and informal. The digital platforms that are used for this political participation are either purpose-made by public institutions (almost all the platforms of participatory budgeting) or repurposed for this (social media platforms for example). It is still early days for e-participation (also evident in the fact that the term has multiple spellings in the literature: eParticipation, e-participation, electronic participation). Researchers found out that, at present, e-participation is "largely confined to the initial and the final stages of the policy cycle and rarely allows for entries into the core stages of decision-making and policy execution" [23].

Participatory budgeting $(\mathrm{PB})$ is part of this newish trend of involving citizens in the decision-making process. In its simplest form, it involves allocating a certain percentage of a community (usually a city) budget towards projects proposed and supported by citizens of that particular community. Nowadays, the whole process typically happens on a software platform that is transparent in all stages of the process: the project proposal phase, the voting phase, the winners' selection phase, and the implementation.

This paper is the first of a larger project that aims to better understand the way in which participatory budgeting is employed in Romania, the reasons that cities choose to create such platforms, the results of these efforts and, if possible, to measure the effectiveness of participatory budgeting initiatives in improving trust in local governments.

\section{Lit review}

The current consensus among researchers is that participatory projects play an increasing role in government, especially local government. PB projects are just one application of this new trend, which also contains other types of platforms (fixmystreet type of apps, e-petitions, e-consultations, etc.) [12][4].

E-participation systems can be viewed as both socio-technical systems and tools for advancing democracy through increasing dialogue between citizens and governments [19]. Local governments are seen, in general, as more trustworthy than central governments [10]. They are also perceived as closer to the citizens' needs and wishes, and more transparent [15], so it is no surprise that PB initiatives are adopted with gusto by city halls and local institutions. Researchers are beginning to test whether PB initiatives are having an effect on citizens' view of their governments, and there are some 
initial encouraging results [22] and signs that citizens are beginning to adopt electronic platforms more widely [9]. Other researchers are skeptical that the promises of e-participation are fulfilled, citing very low participation and the reinforcing of the already existent digital divide [20], arguing that vulnerable groups are excluded and do not benefit from PB [21][17] or that PB's focus almost exclusively on infrastructure investments, which can limit their usefulness [5].

PB has a long history, with the first modern examples in Brazil, at the end of 1980s. The first complete participatory process of this kind was designed and implemented in the city of Porto Alegre, in 1989 [3] (ironically, just as participatory initiatives are mushrooming all around the world, the Porto Alegre PB process was closed down in 2017, after a run of more than 25 years).

The vast majority of such projects were created at local level, by cities big and small, in countries on all continents. According to an estimate of the Participatory Budgeting Project, an international NGO that analyzes this field, participatory budgeting is the most widespread form of participatory democracy, having spread to more than 7,000 communities around the world [18]. The objectives of these types of e-participation systems can range from trying to attract more citizens in the democratic dialogue to increasing trust in institutions [24], combating the so-called democratic deficit and the feeling of alienation among citizens [11], or improving the quality of governance [25]. Moreover, the main reasons for adopting PB by communities seem to be learning and imitation (more studies may reveal if competition also plays a part) [16].

The vast majority of PB processes are, in the taxonomy proposed by Cabannes and Lipietz, territorially based (mostly, like we said, at city level) [7]. Aside from those, PB initiatives can be thematic (dealing with one particular issue, such as transportation or education) or actor-based (with money earmarked for specific vulnerable groups, such as women, youth, or the poor).

There is a reversal of roles in participatory processes. In the Weberian bureaucracy, citizens play little or no part in the decision-making process. Public servants are tasked with all the decisions related to running a community. The direction is now reversed, with citizens having more and more of a say in defining priorities, determining public policies, and funding projects [3].

In almost all cases, the initiative for implementing PB came from governments. If other organizations proposed such a process, there were many constant hurdles and obstacles, especially in the wake of the financial crisis. If the initiative comes from outside (such as from a nonprofit), convincing public officials to allocate funds for this is an extremely difficult endeavor [1].

The scope of this study is only online implementation of the participatory budgeting projects in Romania. The design of PB online platforms differs around the world. In some cases, citizens are only allowed to propose projects, to vote for them (or both). In other cities, discussion forums are created to enable debates or discussions of the proposed projects and to spur support networks for one project or another [13].

PB is a new trend in Romania. The first city to implement such a system (in an offline form, for one neighborhood, with the help of academia and nonprofits) was Cluj-Napoca, in 2013 (in the end, the cost of the projects implemented amounted to almost $€ 4$ million) [5]. After this dress rehearsal, an online PB process called CO'MMON Cluj-Napoca, linked to the European Youth Capital 2015 (a title held by Cluj-Napoca that year), was set up by nonprofits with the help of the local council. 
After these smaller projects, in 2017 Cluj-Napoca implemented the first full online PB process in Romania. All citizens living, studying, or working in Cluj-Napoca could propose projects and vote. During the first phase of the procedure, projects were put forward by citizens, in 6 different categories (alleys, sidewalks, and pedestrian areas; mobility, accessibility, and traffic safety; green areas and playgrounds; arrangements of public spaces (urban furniture, public lighting, etc.); educational and cultural infrastructure; and digital city). After that, each project was evaluated by the City Hall, from both a legal and a technical standpoint. The projects declared eligible went to the first round of voting (where 30 projects were selected). After that, a second round of voting selected the 15 projects to be implemented (each with a maximum budget of $150.000 €$ ).

Being the first of its kind in Romania, this model was adopted in this form (sometimes with small variations) by many Romanian cities that introduced PB in 2018-2019.

\section{Methodology}

During the first phase of our research, we identified Romanian communities that have implemented PB projects in the last 2 years. Through a combination of desk research, media canvassing, conversation with companies that offer PB platforms, and personal contacts inside City Halls, we compiled a list of all PB projects in Romania (17 such projects were identified until January 15, 2020).

After phone contact with each of the 17 City Halls, a questionnaire was sent to the people in charge. In some cases, more phone calls followed, to clarify some data or to get more details. In the end, we received 8 usable responses (a response rate of 47\%). Also, in 2 cities (Braşov and Craiova) the process was ongoing, therefore some data from them will be incomplete.

\section{Results}

The organization of each process was generally the same. At first, citizens or nonprofits could propose projects, usually assigned to categories (with the exception of Florești). These categories could be very broad (like Mobility and accessibility, encountered in most cities) or narrow (Building a skate park, in Arad). The most used categories were Smart city or Digitalization, Mobility and infrastructure, Green spaces and Playgrounds, or Education). The number of categories varied between 5 (Roman) and 9 (Deva).

After that, the City Hall (through a special body created for this purpose) checked the projects for feasibility (from technical and legal point of views). The citizens could then vote for the approved projects (once or in multiple rounds) and the most voted projects went into execution. The citizens that proposed the winning projects did not usually play more than a decorative role in the implementation.

Cluj-Napoca was the first city to implement online participatory budgeting in Romania (it helped that it had experience both with offline PB and with a limited version of online PB) in 2017. After that, other cities took notice and in 2018, PB started in Sibiu, Arad, and in Florești (the biggest rural municipality in Romania, near Cluj-Napoca). In 2019, more cities implemented such a process (Deva, Craiova, Roman, Brașov). It is interesting to note that, out of the 4 cities that started in 2017 or 2018 (Cluj-Napoca, Sibiu, Arad, Florești), only 2 (Cluj-Napoca and Sibiu) managed to have PB each year (Arad and Florești had it for 1 year only and then it stopped). It will be interesting to see how many Romanian communities manage to keep their platforms active. 
The maximum budget per project is, of course, determined also by the financial might of the community. It varies from $€ 20,000$ in Roman to $€ 150,000$ in Cluj-Napoca and Sibiu.

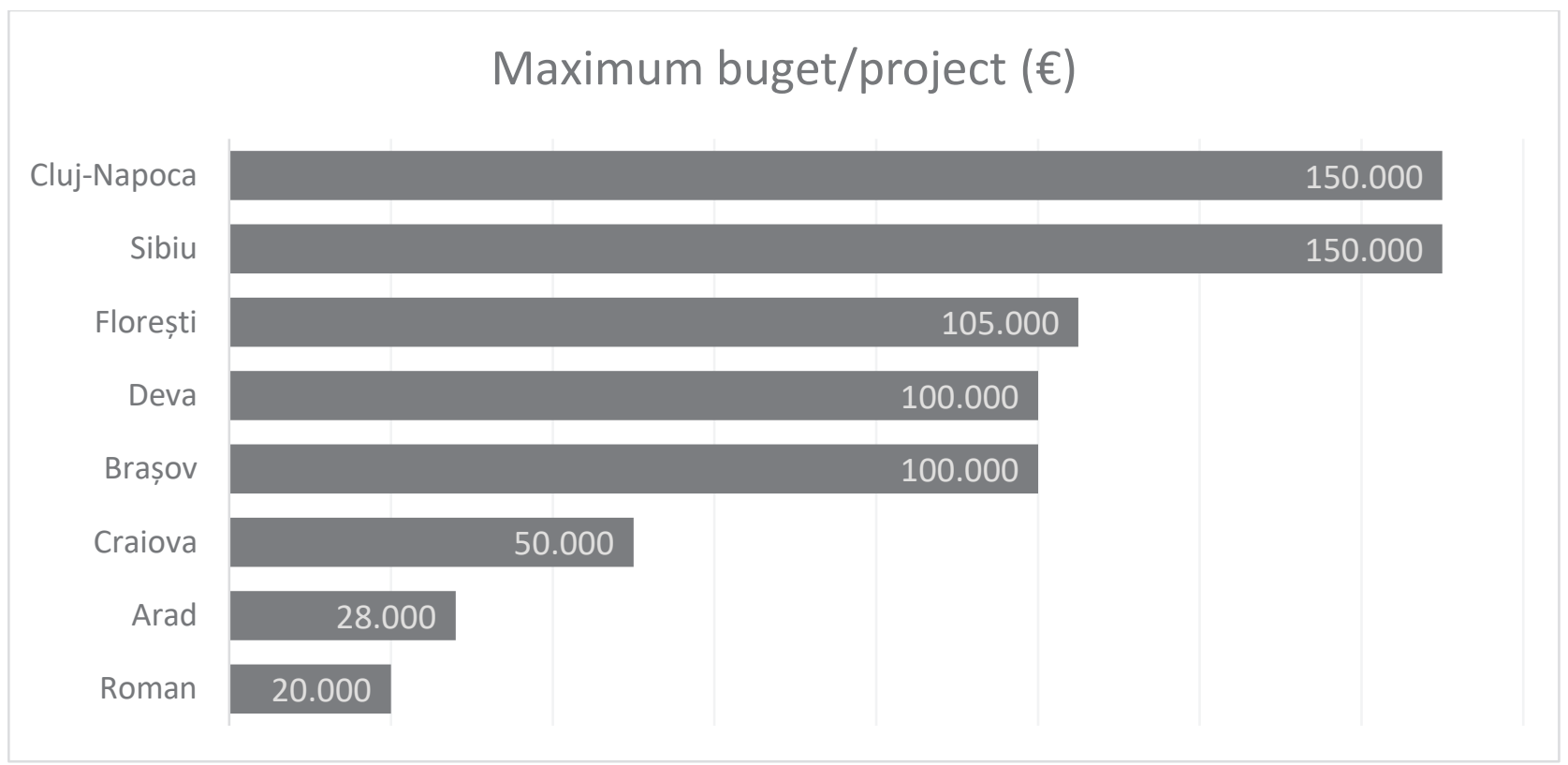

Chart 1: Maximum budget per PB project, by city and year

The percentage of municipal GDP that communities allocate to PB should be a rough indicator of the importance they attribute to this process. Here the differences are also stark:

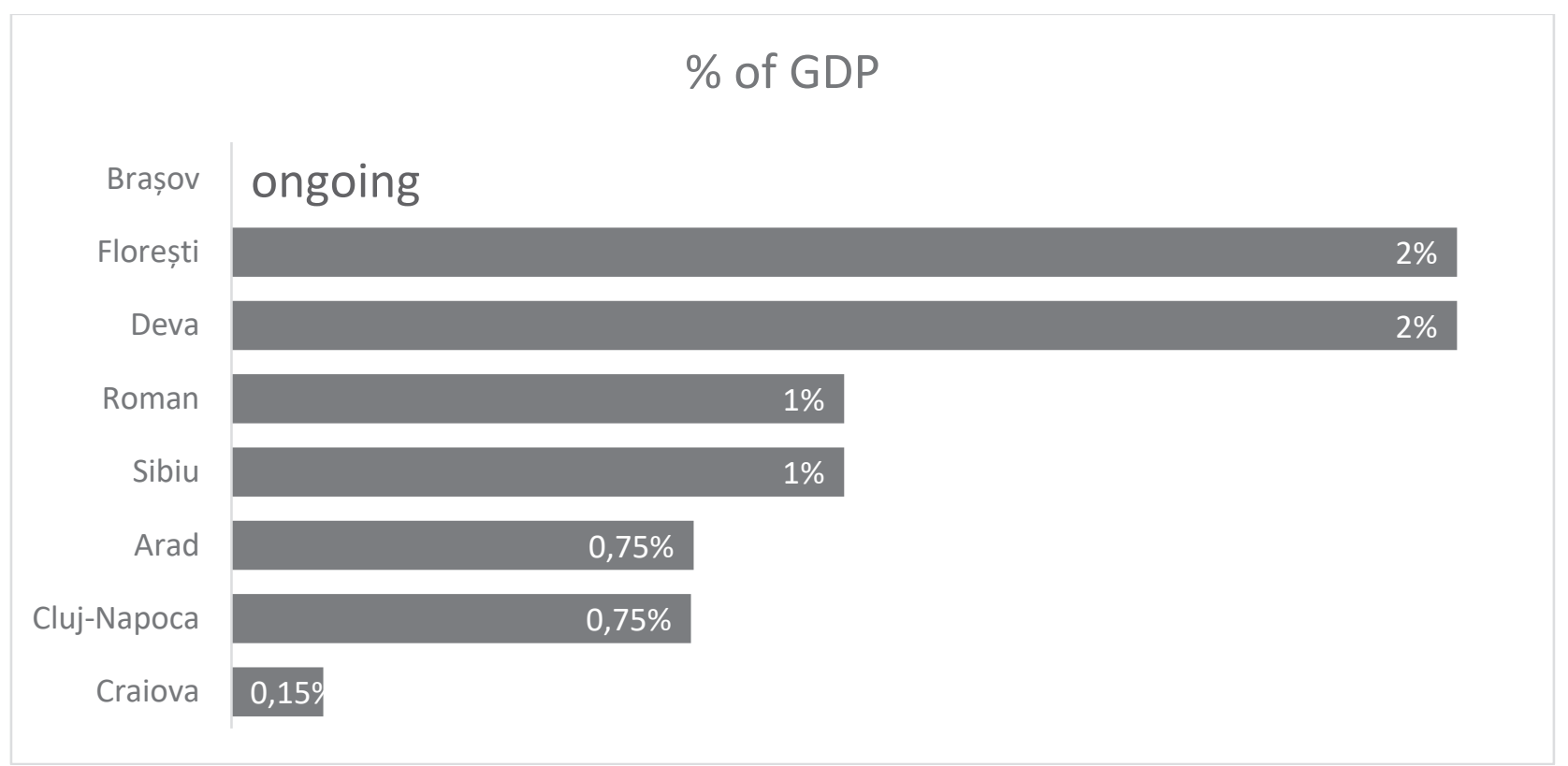

\section{Chart 2: Percentage of city GDP allocated for PB}

The number of projects proposed varies from city to city. Cluj-Napoca and Sibiu vie for the first places by this metric. The size of the city bears an influence, naturally, but it is not the sole determinant: Craiova is almost twice the size of Sibiu, and the number of projects is much higher in Sibiu. 


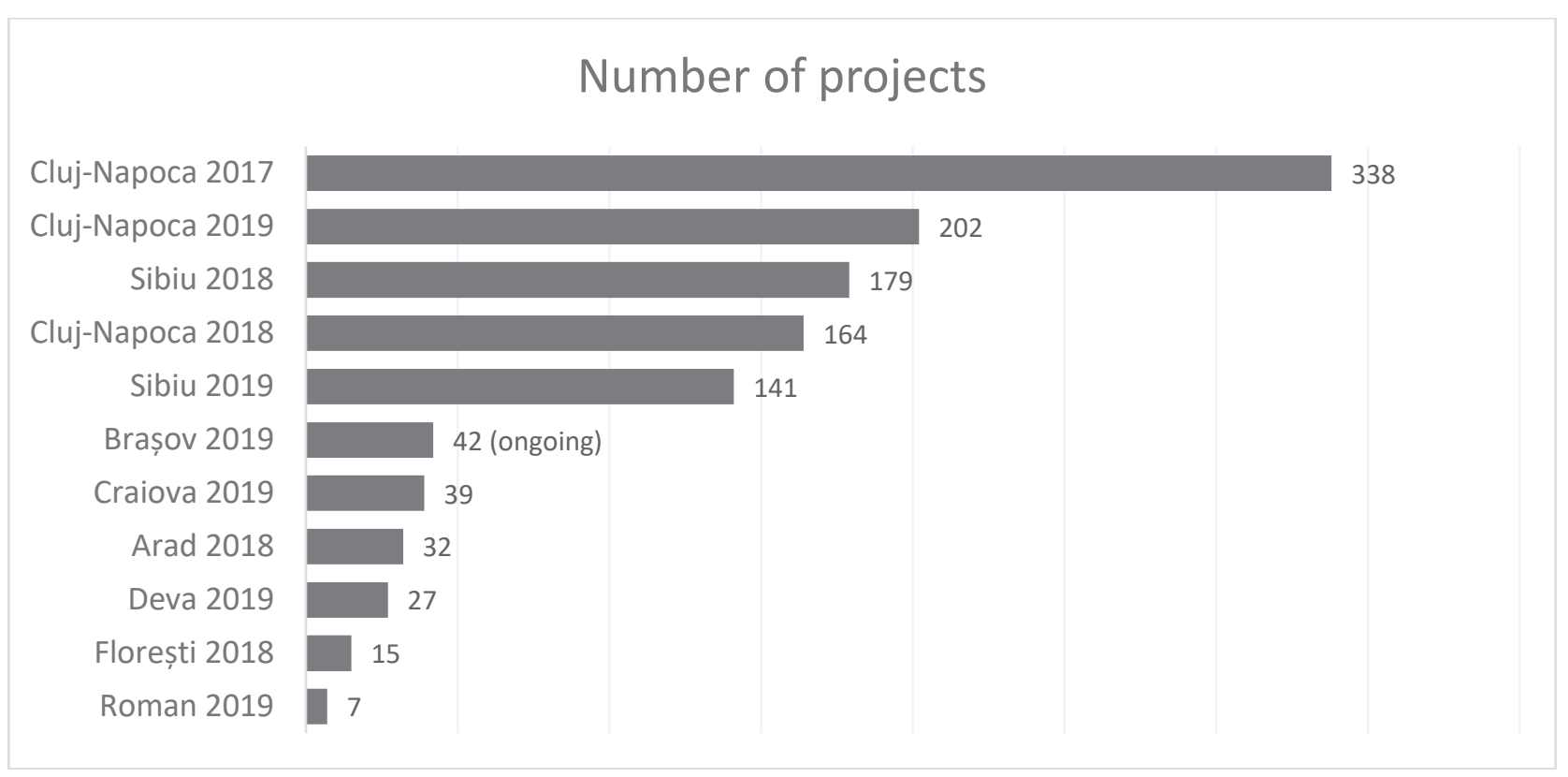

Chart 3: Number of proposed projects, by city and year

The main objective of $\mathrm{PB}$ is involving as many citizens as possible in the process and giving them the tools to influence the way their money is spent in their communities. As such, the number of votes gathered by the proposed projects is an important number by which the success of the PB can be judged.

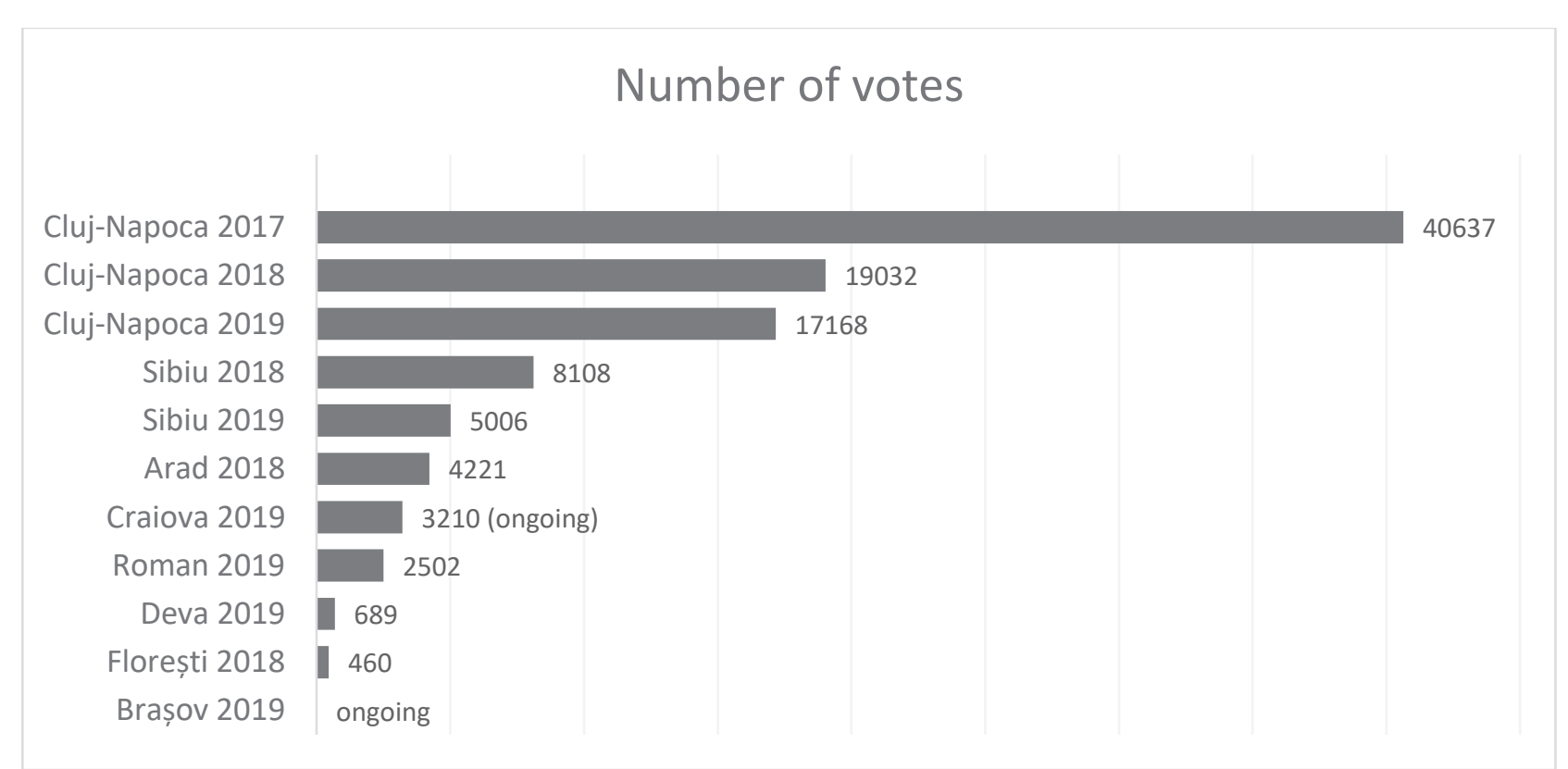

Chart 4: Number of votes for all proposed PB project, by city and year 


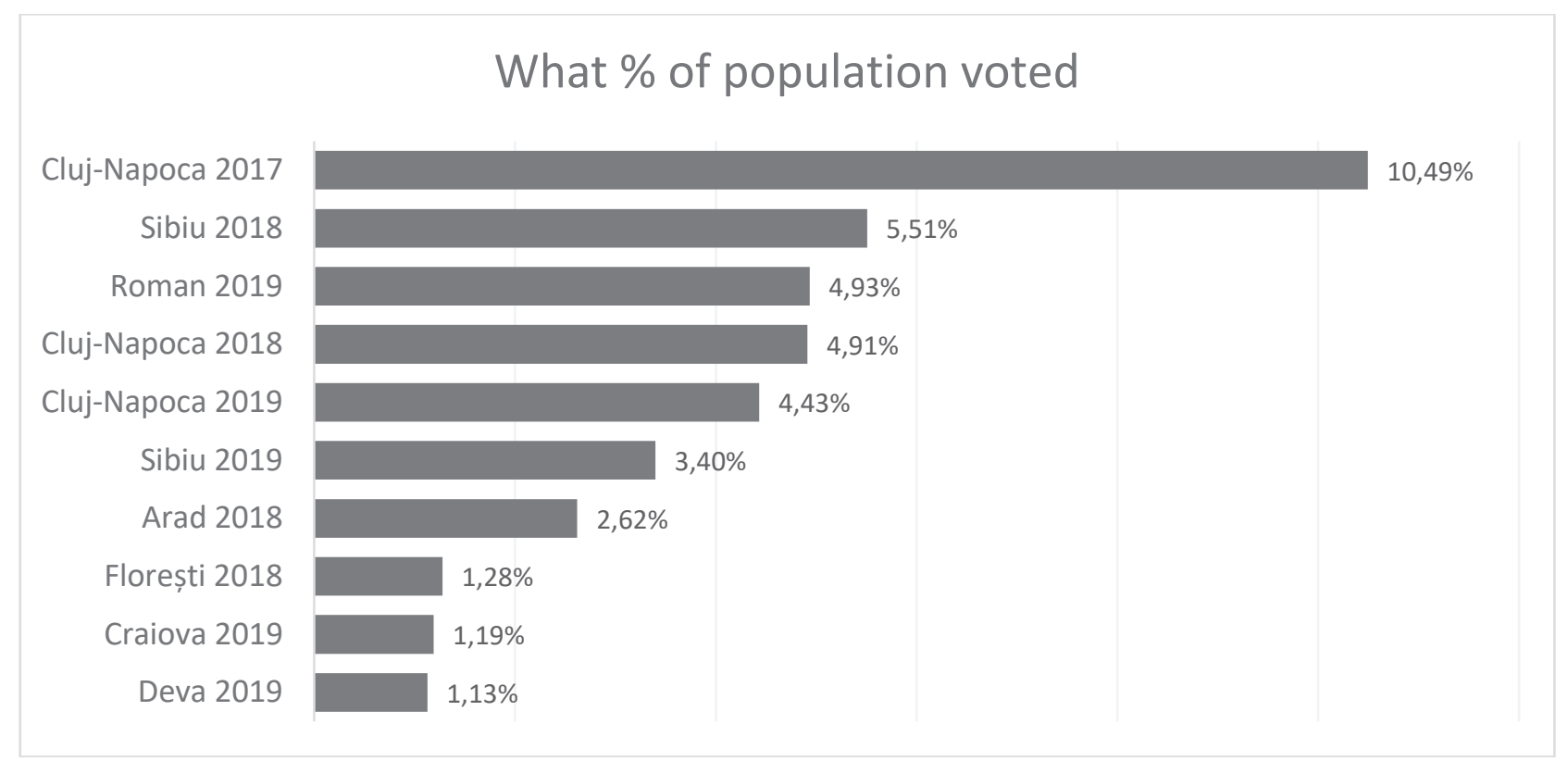

Chart 5: Percentage of population that voted, by city and year

The number of winning projects varies from city to city. If in Cluj-Napoca, in each of the three years, 15 projects were declared winners and implementation started, in Sibiu there were 9 in the first year and 6 in the second year, in Arad 14 in 2018 (after that, Arad dropped PB, at least temporarily), in Deva 6 projects won, in Florești 2 and, in Roman, 1.

City Halls generally under-appreciated the time it took to implement projects proposed through PB. A small number of projects were completed - the cities that provided specific numbers were ClujNapoca (3 projects), Deva (2), Roman (1). Other proposals were in different stages of implementation (42 in Cluj-Napoca, 4 in Arad, 2 in Florești). It is interesting to note that only Cluj-Napoca provides any information on their platform about the stage of implementation of the winning projects.

\section{Discussion}

The theory says that participatory budgeting has the potential to attract people, especially the young and the educated. Detailed data obtained from Cluj-Napoca, from all three years, show that almost 30,000 people participated in PB (in one or more years) and their average age is 37 (at the national level, the average age is 41 ). It is interesting that $31.9 \%$ of those who voted were university students (around $20 \%$ of the population in Cluj-Napoca are university students).

Participation rates are mostly in line with those encountered in other countries. For example, in Eastern European countries, the percentage of citizens involved in PB in cities was between 0.5 and 8.43 in Slovakia, between 0.77 and 6.8 in Croatia, while in Poland the relative indicators are 5.15 to 24.1, depending on the specific cities [9].

In cities that had managed to keep the PB process alive in consecutive years, there seems to be a decrease in participation. A number of factors can explain this trend. The initial novelty determines increased participation, spurred by extensive local media coverage. This freshness wears off in the following years. It is also not helpful that, evident from discussion we had with the public servants in charge of these projects in City Halls around Romania, the marketing campaigns for PB were almost exclusively consigned to the social media accounts of the City Halls. Another possible reason for 
decreasing participation is the small number of projects seen through to the end. The City Halls seem to have overestimated their capacity to implement the winning projects. Also, during the vetting phase (where public servants asses the proposed projects and approve or reject them), there is little transparency on the reasons a particular project is accepted or excluded.

Even if the sums allocated from the city budgets to PB projects are in line with those in other countries, the only cities that come close to spending the full amount are Cluj-Napoca and Sibiu. For the others, the lack of participation or the small number of eligible projects may mean that most of the allocated money will remain unspent.

\section{Conclusions}

Participatory budgeting in Romania is still in its early days. A fair number of cities have implemented such processes and we expect this number to increase in the years to come. Some successful projects were proposed and are either already up-and-running (dedicated public transport lanes for children going to school in Cluj-Napoca, for example) or in the implementation phase (a number of apps that should increase City Halls' transparency and accountability, in a number of cities). On the other hand, citizens are usually held at arm's length, once the voting period has finished, and are not allowed to get involved in the implementation.

Anecdotal evidence tell us that a majority of people in cities that have PB do not know about this processes. A more extensive marketing campaign could reach more citizens and involve them in this opportunity to participate in the betterment of their communities.

City Halls could also be more transparent during both the selection phase and the implementation period, with constant updates and realistic deadlines.

\section{Limits and further research}

This research is just a first step towards understanding the PB projects in Romania. Even if the response rate is relatively good, the small number of cases does not allow us to draw definitive conclusions and generalizations.

Another weakness of this study is the reluctance of some City Halls to release complete data about PB in their communities; we can speculate about the motives (low participation, small number of implemented projects, or lack of technical expertise) but without this data is hard to go more in depth with the analysis.

We will continue to monitor the PB platforms in Romania (both the existing ones and those that will undoubtedly appear in the next years) to fill the gaps in understanding the importance and effects such projects have on communities.

\section{References}

[1] AFONSO, W. B., Citizens Engaging Government: Participatory Budgeting in Greensboro, North Carolina, Public Administration Quarterly, vol. 41 (1), 2017, pp. 7-42. 
[2] AICHOLZER, G. and ROSE, G., "Experience with Digital Tools in Different Types of eParticipation." in L. HENNEN et al. (eds.), European E-Democracy in Practice, Studies in Digital Politics and Governance, Springer, 2020.

[3] ARAGONES, E. and SANTIAGO, S-P., A theory of participatory democracy based on the real case of Porto Alegre, European Economic Review, 53, 2009, pp. 56-72.

[4] AVRITZER, L., Participation in democratic Brazil: from popular hegemony and innovation to middle-class protest, Opinião Pública, vol. 23 (1), 2017, pp. 43-59.

[5] BOC, E., The Development of Participatory Budgeting Processes in Cluj-Napoca, Transylvanian Review of Administrative Sciences, 58E, 2019, pp. 38-51.

[6] BOUCKAERT, G., Trust and public administration, Administration, vol. 60 (1), 2012, pp. 91115.

[7] CABANNES, Y. and LIPIETZ, B., Revisiting the democratic promise of participatory budgeting in light of competing political, good governance and technocratic logics, Environment \& Urbanization, vol. 30 (1), 2017, pp. 67-84.

[8] DALTON, R. J., Citizen Politics: Public opinion and political parties in advanced industrial democracies, 3rd ed., Chatham House Press, New York, 2002.

[9] DŽINIĆ, J., SVIDROŇOVÁ, M.M., and MARKOWSKA-BZDUCHA, E., Participatory Budgeting: A Comparative Study of Croatia, Poland and Slovakia, NISPAcee Journal of Public Administration and Policy, vol. 9 (1), 2016, pp. 31-56.

[10] EDELMAN TRUST BAROMETER, 2020, Retreived on February 2, 2020 (https://www.edel man.com/sites/g/files/aatuss191/files/202001/2020\%20Edelman\%20Trust $\% 20$ Barometer $\% 20$ Global\%20Report.pdf).

[11] GOMEZ, J., RIOS INSUA, D., LAVIN, J. M., and ALFARO, C., On deciding how to decide: Designing participatory budget processes, European Journal of Operational Research, vol. 229, 2013, pp. 743-750.

[12] HALTOFOVA, B., Fostering Community Engagement through Crowdsourcing: Case Study on Participatory Budgeting, Theoretical and Empirical Researches in Urban Management, vol. 13 (1), 2018, pp. 5-12.

[13] IASULAITIS, S., PINEDA NEBOT, C., da SILVA, E.C. and SAMPAIO, R.C., Interactivity and policy cycle within Electronic Participatory Budgeting: a comparative analysis, Journal of Public Administration, vol. 53 (6), 2019, pp. 1091-1115.

[14] IM, T., CHO, W., PORUMBESCU, G. and PARK, J., Internet, Trust in Government, and Citizen Compliance, Journal of Public Administration Research and Theory, vol. 24 (3), July 2014, pp. 741-763.

[15] KIM, S. and LEE, J., E-Participation, Transparency, and Trust in Local Government, Public Administration Review, vol. 72 (6), 2012, pp. 819-828. 
[16] KRENJOVA, J. and RAUDLA, R., Policy Diffusion at the Local Level: Participatory Budgeting in Estonia, Urban Affairs Review, vol. 54 (2), 2018, pp. 419-447.

[17] PAPE, M. and LIM, C., Beyond the "Usual Suspects"? Reimagining Democracy With Participatory Budgeting in Chicago, Sociological Forum, vol. 34 (4), 2019, pp. 861-882.

[18] PARTICIPATORY BUDGETING PROJECT (PBP), Global Participatory Budgeting Hub, Retrieved January 13, 2020, (https://www.participatorybudgeting.org/globalpbhub/)

[19] PORWOL, L., OJO, A. and BRESLIN, J., On the Duality of E-Participation - Towards a Foundation for Citizen-Led Participation, at International Conference on Electronic Government and the Information Systems Perspective, 2013.

[20] PROSSER, A., eParticipation - Did We Deliver What We Promised?, International Conference on Electronic Government and the Information Systems Perspective, 2012.

[21] SAGUIN, K., Why the poor do not benefit from community-driven development: Lessons from participatory budgeting, World Development, vol. 112, 2018, pp. 220-232.

[22] SWANER, R., Trust Matters: Enhancing Government Legitimacy through Participatory Budgeting, New Political Science, vol. 39 (1), 2017, pp. 95-108.

[23] van DIJK, J. A. G. M., "Digital democracy: Vision and reality." in I. Snellen, M. Thaens, $\& W$. van de Donk (eds.), Public administration in the information age: Revisited, IOS-Press, Amsterdam, 2012.

[24] WARREN, A. M., SULAIMAN, A. and JAAFAR, N. I., Social media effects on fostering online civic engagement and building citizen trust and trust in institutions, Government Information Quarterly, vol. 31 (2), 2014, pp. 291-301.

[25] WIRTZ, B. W., DAISER, P. and BLINKOWSKA, B., E-participation: A Strategic Framework, International Journal of Public Administration, vol. 41 (1), 2018, pp. 1-12 